\title{
Nickel and vanadium contamination of benthic invertebrates following the "Erika" wreck
}

\author{
Jean-François Chiffoleau ${ }^{1, a}$, Laurent Chauvaud ${ }^{2}$, David Amouroux ${ }^{3}$, Aurélie Barats ${ }^{3}$, Aurélie Dufour ${ }^{1}$, \\ Christophe Pécheyran ${ }^{3}$ and Nathalie Roux ${ }^{1}$ \\ IFREMER, Département DEL/PC, BP 21105, 44311 Nantes Cedex 3, France \\ 2 IUEM, UMR CNRS 6539 (Lemar), Technopôle Brest-Iroise, Place N. Copernic, 29280 Plouzané, France \\ 3 Laboratoire de Chimie analytique bio-inorganique et Environnement, CNRS UMR 5034, Université de Pau et des Pays de l'Adour, \\ 64053 Pau Cedex 9, France
}

Received 10 February 2004; Accepted 26 May 2004

\begin{abstract}
Levels of nickel and vanadium, trace metals found in high concentration in the oil spilled from the "Erika" tanker off Brittany (France) in December 1999 (41 \pm 1 and $87 \pm 3 \mathrm{mg} \mathrm{kg}^{-1}$ respectively), have been monitored over a one-year period following this accidental event in several benthic invertebrates. Ni and V in mussels (Mytilus edulis) and oysters (Crassostrea gigas) soft tissues were analysed twice a month by graphite furnace atomic absorption spectrometry and a scallop (Pecten maximus) shell daily growth bands were sampled every three bands by laser ablation and analysed by ICP-MS for these two contaminants. Survey data for mollusc tissues were compared with reference data arising from the national monitoring database. Ni concentrations in dried tissues, comparable with reference data $\left(1.8 \pm 0.9 \mu \mathrm{g} \mathrm{g}^{-1}\right.$ in mussels and $1.2 \pm 0.5 \mu \mathrm{g} \mathrm{g}^{-1}$ in oysters) do not show any additional input during the whole period. Conversely, a sharp increase in vanadium concentrations (up to 4.6 and $3.2 \mu \mathrm{g} \mathrm{g}^{-1}$ for mussels and oysters respectively) is observed around May 2000, i.e. 5 months after the wreck, compared with the monitoring data $\left(1.4 \pm 0.6 \mu \mathrm{g} \mathrm{g}^{-1}\right.$ in mussels and $1.3 \pm 0.6 \mu \mathrm{g} \mathrm{g}^{-1}$ in oysters). Furthermore, no Ni peak is detectable in the time profiles of scallop shell growth bands where a V peak is observed also in May 2000. This study shows that although a "mussel-watch-type" network, based on the monitoring of vanadium concentration in mollusc tissues, is able to identify contamination due to oil spills, similar information might be obtained a posteriori by analysing daily growth bands of scallop shells.
\end{abstract}

Key words: Oil spill / Nickel / Vanadium / Mussel / Oyster / Scallop shell / Monitoring

Résumé - Résumé. Contamination des invertébrés benthiques par le nickel et le vanadium suite au naufrage de l'«Erika ». Les concentrations en nickel et en vanadium, métaux traces présents en quantité importante dans le fioul échappé du pétrolier «Erika» au large de la Bretagne (France) en décembre 1999 (41 \pm 1 et $87 \pm 3 \mathrm{mg} \mathrm{kg}^{-1}$ respectivement) ont fait l'objet d'un suivi d'un an après le naufrage chez quelques invertébrés benthiques. Ni et V ont été analysés deux fois par mois dans les tissus mous de moules (Mytilus edulis) et d'huîtres (Crassostrea gigas) par absorption atomique à four graphite et tous les trois jours dans les stries journalières de croissance des valves d'une coquille Saint-Jacques (Pecten maximus) par ICP-MS après ablation laser. Les données obtenues pour les tissus de mollusques ont été comparées avec les valeurs de références fournies par le programme national de surveillance. Durant toute la période d'étude, on n'observe pas d'apport occasionnel en nickel, dont les concentrations dans la chair séchée sont comparables aux valeurs de référence $\left(1,8 \pm 0,9 \mu \mathrm{g} \mathrm{g}^{-1}\right.$ chez les moules et $1,2 \pm 0,5 \mu \mathrm{g} \mathrm{g}^{-1}$ chez les huîtres). En revanche, une élévation importante des concentrations en vanadium (jusqu'à 4,6 et $3,2 \mu \mathrm{g} \mathrm{g}^{-1}$ chez les moules et les huîtres respectivement) comparées aux donnés de la surveillance $\left(1,4 \pm 0,6 \mu \mathrm{g} \mathrm{g}^{-1}\right.$ chez les moules et $1,3 \pm 0,6 \mu \mathrm{g} \mathrm{g}^{-1}$ chez les huîtres), est observée en mai 2000 , soit 5 mois après le naufrage. De la même manière, aucun pic de nickel n'a été détecté dans les profils temporels de stries journalières de coquille de pectinidé alors qu'un pic de vanadium est observable en mai 2000. Cette étude montre qu'un réseau d'observation de type «mussel-watch » basé sur la surveillance des concentrations en vanadium dans les tissus de mollusques est apte à identifier une contamination due à une marée noire, et une information du même type pourrait être obtenue a posteriori en analysant les stries journalières des valves de coquilles Saint-Jacques.

\footnotetext{
a Corresponding author: jfchiffo@ifremer.fr
} 


\section{Introduction}

Most of the oil discharged in the environment originates from natural sources and fuel oil consumption - this last category includes industrial discharges and vehicle emissions. Since the middle of the seventies, about 100000 tons of oil have been discharged annually in the marine environment due to oil tanker accidents. The number of accidental spills has however highly decreased over the years and nowadays, oil contamination is mostly attributable to a limited number of oil tanker accidents (Anderson and Labelle 2000). Among the latter, the Erika shipwreck on December 12, 1999, in the Bay of Biscay, France, which spilled about 20000 tons of No. 2 fuel oil off the shores of South Brittany (Le Hir and Hily 2002). This region of Western Europe has experienced 7 major oil spills over the last 30 years (Dyrynda et al. 2000).

Following these accidents, a number of scientific studies on the impact of oil spills on coastal ecosystems were carried out, notably on hydrocarbons, the highly toxic chief constituents of petroleum products (Seip 1984; Highsmith et al. 1996; Lee and Page 1997; Jones et al. 1998; Law et al. 1999). However, although petroleum products also contain significant concentrations of trace metals (Metwalli et al. 1997; Márquez et al. 1999), so far few studies have focused on the impact of these elements on the environment. Studies by Bu-Olayan and Al Yakoob (1998) and Cantu et al. (2000), for instance, show that nickel and vanadium are not very mobile in fuel oil, and consequently their transfer to the aqueous phase is extremely slow. Vanadium is however proposed as an internal marker for the monitoring of microbial degradation of crude oil (Sasaki et al. 1998). As nickel and vanadium are increasingly integrated in marine monitoring programs, it is thus crucial to study the impact of an oil tanker accident on the levels of these elements in coastal organisms, namely in species used as bioindicators in these programs.

For 25 years, the National Network for the Observation of Marine Environment Quality (RNO, the French MusselWatch) has been regularly (once every three months) measuring concentrations of certain chemical contaminants in oyster and mussel tissues (Claisse 1989). This valuable database (80 sampling stations distributed along the French coasts) is used as a reference to either identify trends toward contamination/decontamination with specific contaminants, or accidental-type peak concentrations. Moreover, all collected samples are stored in an organism bank. Although nickel and vanadium were not part of the list of contaminants that were monitored by the RNO at the time of the Erika wreck, it has been possible to define the coastal mollusc nickel and vanadium contamination situation before the wreck, inside and outside of the area affected by the oil spill, a posteriori using this organism bank. Additional samplings (increased frequency at the original sampling sites and additional sites) allowed us to refine our observations.

This study was complemented by a very high frequency monitoring on mollusc shells during that same period. It has been known that molluscs, bivalves in particular, accumulate certain metal contaminants, such as cadmium (Sturesson 1978), lead (Sturesson 1976), vanadium (Miramand et al. 1980) in their shell. Richardson et al. (2001) showed, using laser ablation-ICP-MS, that metal concentration varies as a

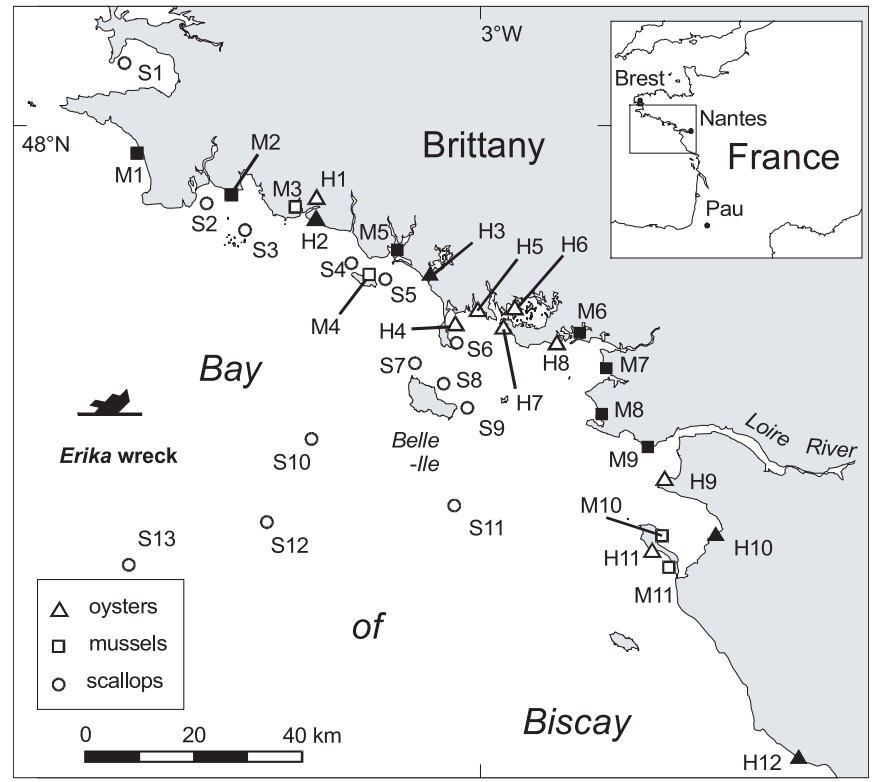

Fig. 1. Study site and sampling strategy. Black symbols refer to the RNO sampling stations.

function of age in horse mussel (Modiolus modiolus) shell. We developed a high frequency monitoring method for the measurement of metal concentration in scallop (Pecten maximus) shells, which consists in analysing daily growth bands using this same laser ablation technique. This method was used for the study of scallops collected in the area where the wreck occurred. As opposed to the classical mussel-watch sampling strategy, this method offers the unquestionable advantage of being able to be performed after an unforeseeable event.

\section{Material and methods}

\subsection{Site of study and sampling strategy}

Bivalves (mussels, oysters, cockles, tellins, clams) and crustaceans (barnacles) were sampled immediately after the Erika wreck and before oil slicks reached the shore (between December 12 and 24, 1999). Sampling was done by hand, according to international quality assurance guidelines (Claisse 1989), in nearly thirty sites along the northern coastline of the Bay of Biscay in order to complement the sampling strategy of the RNO and define very precisely the initial conditions for subsequent expertise. During the following year (year 2000), these sites were surveyed semi-monthly. Part of the samples (stations M1 to M11 for mussels, stations H1 to H12 for oysters) were used for the study of nickel and vanadium contamination (Fig. 1).

As for coastal molluscs, selected sites to study contamination in scallops were located in the area that had been hit by oil slicks and at its outermost limits. Stations S1 to S13 were sampled (Fig. 1) in this area from October 2001 to March 2002, mostly by dredging, with a chartered fishing boat, and sometimes by scuba diving. Scallops collected at each site were usually of different age groups, however analyses focused on 
Table 1. Quality control results (Concentrations are expressed in $\mu \mathrm{g} \mathrm{g}^{-1} \mathrm{dw}$ ).

\begin{tabular}{cccccc}
\hline & Nickel & & \multicolumn{2}{c}{ Vanadium } \\
SRM 2976 & SRM 1566b & TORT-2 & SRM 2976 & SRM 1566b & TORT-2 \\
\hline 0.09 & 0.09 & 0.09 & 0.5 & 0.5 & 0.5 \\
$0.9 \pm 0.1$ & $1.0 \pm 0.2$ & $2.5 \pm 0.2$ & $1.5 \pm 0.2$ & $0.57 \pm 0.08$ & $2.0 \pm 0.2$ \\
$0.93 \pm 0.12$ & $1.04 \pm 0.09$ & $2.3 \pm 0.3$ & - & $0.58 \pm 0.02$ & $1.6 \pm 0.2$ \\
\hline
\end{tabular}

scallops of less than 3 years. In this work we present preliminary results obtained from a single scallop shell collected off Belle-Ile.

\subsection{Collection, treatment, and analysis}

\section{Fuel oil}

$150 \mathrm{mg}$ of Erika fuel oil (collected by the CEDRE, Centre of Documentation, Research and Experimentation on the accidental Pollutions of Waters) were mineralised in a microwave oven at $180{ }^{\circ} \mathrm{C}$ during 2 hours by $10 \mathrm{ml}$ nitric acid. Nickel and vanadium were analysed by graphite furnace atomic absorption spectrometry (VARIAN model AA800) with Zeeman background correction.

\section{Mussel and oyster tissues}

Following the recommendations of Cossa (1989) related to the statistical significance of sampling, each sample consisted of a pool of at least 50 mussels (Mytilus edulis) or 10 oysters (Crassostrea gigas) of the same size or age range (35-60 $\mathrm{mm}$ for mussels, 2 years for oysters), ensuring a good estimation of the average concentration of the population studied; molluscs were collected at low tide, immediately packed in plastic bags, and kept at $+4{ }^{\circ} \mathrm{C}$ during transport (Claisse 1989). Back in the laboratory, soft tissues were removed from their shells, pooled, homogenised, and freeze-dried.

As per the protocol used by the RNO (Chiffoleau et al. 2002), aliquots of $200 \mathrm{mg}$ of dried samples were mineralised at $90{ }^{\circ} \mathrm{C}$ with nitric acid under atmospheric pressure. Nickel and vanadium were analysed by graphite furnace atomic absorption spectrometry (VARIAN model AA800) with Zeeman background correction.

Polycyclic aromatic hydrocarbon (PAH) concentrations (the sum of 16 PAH surveyed on a routine basis, i.e. naphtalene, acenaphtylene, acenaphtene, fluorene, phenanthrene, anthracene, fluoranthene, pyrene, benzo(a)anthracene, chrysene, benzo(a)fluoranthene, benzo(k)fluoranthene, benzo(a)pyrene, dibenzo(a,h)anthracene, benzo $(\mathrm{g}, \mathrm{h}, \mathrm{i})$ perylene, indeno(1,2,3cd)pyrene) are reported from Chantereau et al. (2003).

Quality assurance relies on the systematic control of blanks and on the determination of the accuracy and reproducibility of measurement conditions using certified reference material.

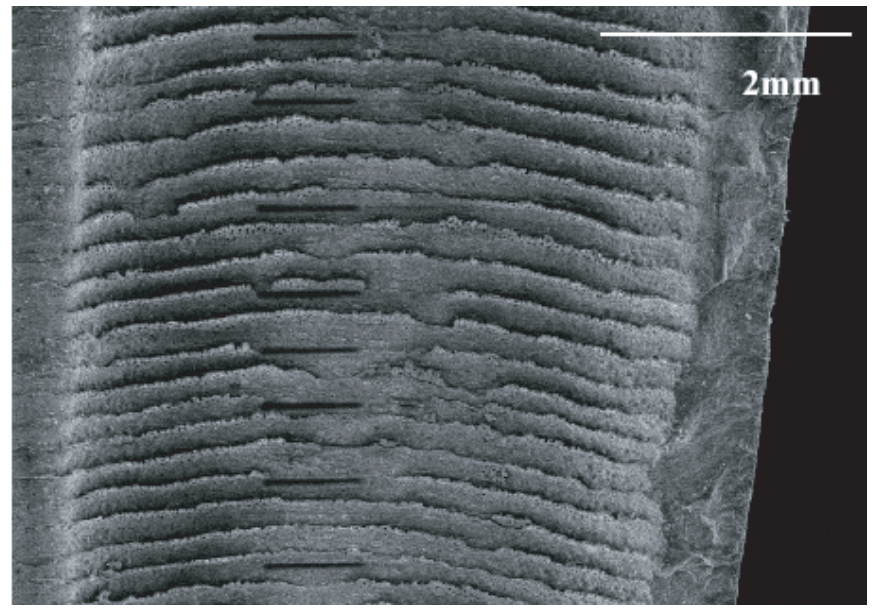

Fig. 2. Ablated microgrooves (dark lines) on daily growth bands (1 of 2) of a scallop shell.

We participate in interlaboratory comparisons, such as the E.U. project QUASIMEME, on a regular basis. The standards used in this study were the SRM 2976 mussel tissue and the SRM $1566 \mathrm{~b}$ oyster tissue from the National Institute for Standards and Technology (USA), and the CRM TORT-2 lobster liver from the National Research Council Canada. The control data are reported in Table 1.

\section{Scallop shells}

Once collected scallops (Pecten maximus) extracted from their shell, left valves were cleaned with acetic acid for one minute for better visualisation of growth bands, rinsed with milli-Q water, and dried. Sections of shells just big enough to fit into the ablation chamber (approximately $20 \times 45 \mathrm{~mm}$ ) were cut with a diamond saw. On each shell, growth bands (1 of 2) were ablated with a beam of approximately $50 \mu \mathrm{m}$ in width, using a LSX 100-Cetac laser consisting of a (UV) Nd:YAG crystal operating at $266 \mathrm{~nm}$ according to the conditions described in Table 2. A complete study conducted in laboratory showed that the best strategy consists in ablating each band lenghtwise, thus forming microgrooves (Fig. 2). This approach allows smoothing of data on a representative sample of the band and avoids dealing with artefacts that may be caused by inclusions in the shell. Moreover, it improves signal reproducibility. 
Table 2. Conditions used for laser ablation - ICP-MS.

\begin{tabular}{|l|}
\hline Laser: CETAC LSX 100 \\
Wavelength: $266 \mathrm{~nm}$ \\
Laser mode: Q-switched, defocus $500 \mu \mathrm{m}$ \\
RF power: $\sim 0.7 \mathrm{~mJ}$ \\
Repetition rate: $20 \mathrm{~Hz}$ \\
Scanning speed: $5 \mu \mathrm{m} \mathrm{s}^{-1}$ (analysis), $50 \mu \mathrm{m} \mathrm{s}^{-1}$ (stripping) \\
Duration of ablation: $120 \mathrm{~s}$ \\
Length of the ablated segment: $\sim 600 \mu \mathrm{m}$ \\
\\
ICP-MS: X7 Thermo Elemental \\
Cones: platinum \\
Plasma power: $1350 \mathrm{~W}$ \\
Argon flow rate: \\
Plasmagen: $14 \mathrm{~L} \mathrm{~min}{ }^{-1}$ \\
Auxiliary: $1.1 \mathrm{~L} \mathrm{~min}{ }^{-1}$ \\
Nebulizers: $1.1 \mathrm{~L} \mathrm{~min}{ }^{-1}$ \\
Dwell time: $20 \mathrm{~ms}$ \\
Number of isotopes: 23 \\
Signal processing: "TRA Profile" mode (Thermoelemental \\
Plasmalab software) \\
\hline
\end{tabular}

Thus in each band, a segment of approximately $600 \mu \mathrm{m}$ in length was analysed in $2 \mathrm{~min}$.

Analyses of the ablated aliquot were done on a X7 Thermo-Elemental ICP-MS (Inductively Coupled Plasma Mass Spectrometer) according to the conditions described in Table 2. Several isotopes were simultaneously recorded: ${ }^{51} \mathrm{~V}$, ${ }^{58} \mathrm{Ni},{ }^{60} \mathrm{Ni}$, and ${ }^{43} \mathrm{Ca}$. As calcium is the chief constituent of the carbon skeleton of scallops (40\% on average; cf. Larvor 1996), it is also the most homogenous element in the matrix and can be considered constant in the shell; for that reason it was used as an internal standard for drift correction that may be caused by laser ablation or ICP-MS detection and thus signals obtained for nickel and vanadium were systematically normalised with ${ }^{43} \mathrm{Ca}$. Analyte quantification was carried out using calcite standards prepared in the laboratory from ultrapure calcite to which known quantities of metals were added by coprecipitation. Compact pellets were thus produced and ablated the same way the scallop shells were in order to generate an external standard curve.

\section{Results}

\section{1 $\mathrm{Ni}$ and $\mathrm{V}$ concentration in fuel oil}

The concentrations of nickel and vanadium in crude oil are highly variable depending of the oil source, ranging from 2 to $200 \mathrm{mg} \mathrm{kg}^{-1}$ for nickel (Vale et al. 2004) and from 0.02 to $1180 \mathrm{mg} \mathrm{kg}^{-1}$ for vanadium (Crans et al. 1998). In the Erika fuel oil, concentrations of $41 \pm 1 \mathrm{mg} \mathrm{kg}^{-1}$ and $87 \pm 3 \mathrm{mg} \mathrm{kg}^{-1}$ have been measured for nickel and vanadium respectively. As a comparison, they are of the same order although slightly lower than those of the fuel spilled from the PRESTIGE tanker off
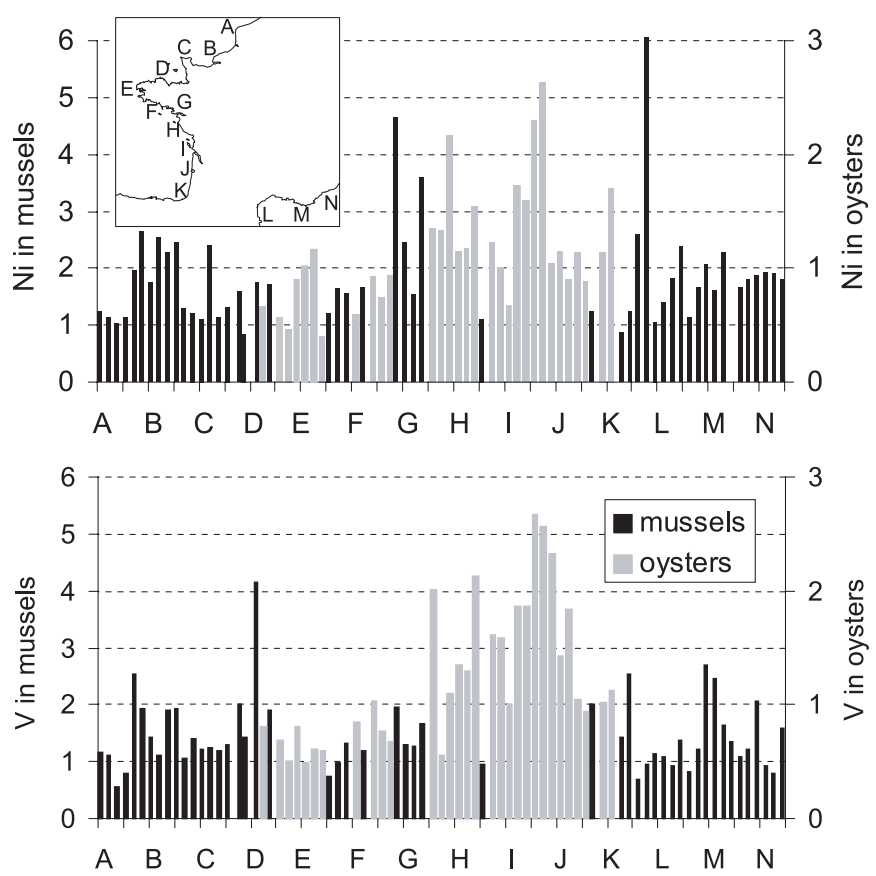

Fig. 3. Spatial distribution of nickel and vanadium concentrations in French seashore molluscs ( $\mu \mathrm{g} \mathrm{g}^{-1}$ dry weight) in February 1999.

Spain in November 2002, evaluated by our laboratory and the same method at $55 \pm 1 \mathrm{mg} \mathrm{kg}^{-1}$ and $170 \pm 5 \mathrm{mg} \mathrm{kg}^{-1}$ for $\mathrm{Ni}$ and $\mathrm{V}$ respectively.

\subsection{Characterisation of initial conditions}

The initial conditions were defined based on samples from the RNO. The RNO has been measuring concentrations of a number of contaminants in oysters and mussels 4 times a year since 1979 (Claisse 1989) in nearly 80 sampling stations distributed along the French shoreline (Chiffoleau and Bonneau 1994). Although nickel and vanadium were not included in the list of monitored contaminants until 2003, a retrospective analysis of these elements was conducted on samples that had been collected before the oil spill, freeze-dried, and stored in an organism bank belonging to the RNO. Spatial variability in nickel and vanadium concentrations was characterised using samples collected during the first trimester of 1999, whereas seasonal variability was defined based on samples collected during all four trimesters of the four years that preceded the shipwreck.

Spatial distribution. On the French coasts, nickel concentrations (Fig. 3) varied from 0.8 to $6.1 \mu \mathrm{g} \mathrm{g}^{-1}$ dry weight (dw) in mussel tissues (mean: $1.8 \pm 0.9 \mu \mathrm{g} \mathrm{g}^{-1} \mathrm{dw}$ ) and from 0.4 to $2.6 \mu \mathrm{g} \mathrm{g}^{-1} \mathrm{dw}$ in oyster tissues (mean: $1.2 \pm 0.5 \mu \mathrm{g} \mathrm{g}^{-1} \mathrm{dw}$ ). No areas were found to be contaminated as a whole by nickel, however certain sites seemed relatively rich in nickel when compared to the seashore mean concentration. It was actually the case for the Loire (region G) and the Gironde (region I) estuaries, on the Atlantic coast, and on the Mediterranean coast, the Pond de Bages (region L). On the south coasts of Brittany (region F), mussels and oysters were not found to be chronically contaminated by nickel. 


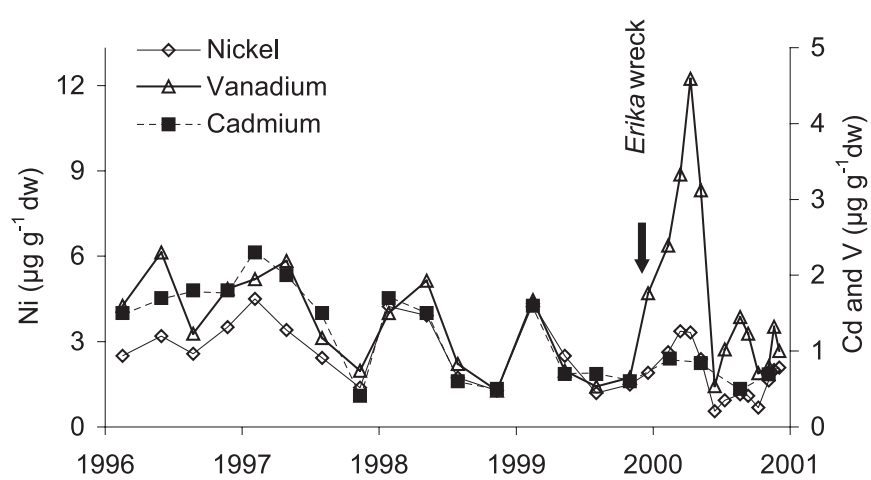

Fig. 4. Time evolution of cadmium, nickel, and vanadium concentrations in mussels ( $\mu \mathrm{g} \mathrm{g}^{-1}$ dry weight) at Erfosse (station M6) before and after the Erika wreck.

Concentrations in vanadium (Fig. 3) ranged from 0.6 to $4.1 \mu \mathrm{g} \mathrm{g}^{-1} \mathrm{dw}$ in mussel tissues (mean: $1.4 \pm 0.6 \mu \mathrm{g} \mathrm{g}^{-1} \mathrm{dw}$ ), and from 0.5 to $2.7 \mu \mathrm{g} \mathrm{g}^{-1} \mathrm{dw}$ in oyster tissues (mean: $1.3 \pm$ $0.6 \mu \mathrm{g} \mathrm{g}^{-1} \mathrm{dw}$ ). Unlike for nickel, the entire Gironde estuary region (region I) appeared to be contaminated with vanadium, this contamination could still be detected further North, up to the Vendée coasts (region $\mathrm{H}$ ).

Temporal variability of concentrations. During the 4 years preceding the Erika wreck, we observed a seasonal cycle of nickel and vanadium concentrations in mussels, such as in Erfosse (station M6) for example, which was characterised by high values in the winter and much lower values in the summer and fall (Fig. 4). These seasonal variations, due to physiologic changes occurring in these organisms throughout the year (reproductive cycle), are typically observed in monitoring programs (Beliaeff and Smith 1996). We noted that concentration variations (by a factor on the order of 3) are perfectly superimposable for nickel and vanadium on the one hand, and cadmium, an element that has been monitored by the RNO for over 20 years, on the other hand. In oysters, seasonal variations before the Erika wreck were much less regular, as seen in samples from Riec sur Bélon (station H2), and while nickel concentrations superimposed relatively well with cadmium concentrations, it was not so for vanadium concentrations (Fig. 5). Evolution of the latter sometimes appeared phase shifted with that of the other elements considered, notably in 1997 and 1998. However the amplitude of the variation in the concentration of these 3 elements was comparable, and was, as for mussels, of a factor on the order of 3 .

\subsection{Evolution of nickel and vanadium concentrations following the Erika wreck}

Mussels and oysters. In a very large part of the sampled stations, we observed after the wreck of Erika an evolution of concentrations such as that observed in mussels from Erfosse (Fig. 4) and oysters from Riec sur Bélon (Fig. 5). As early as the first months of 2000, a peak in nickel concentrations slightly distinct from the cadmium curve was observed in mussels as well as in oysters. The amplitude of the variations in nickel concentration in these two species was however not larger than that observed before the wreck. This peak cannot be

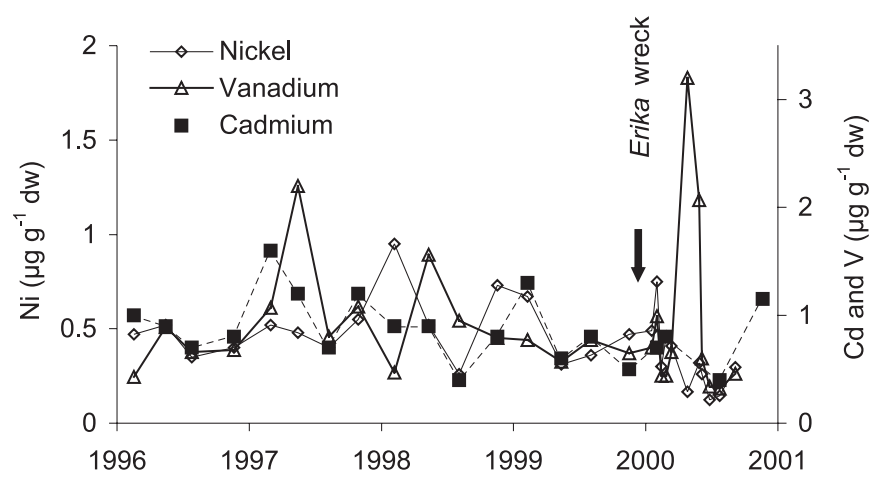

Fig. 5. Time evolution of cadmium, nickel, and vanadium concentrations in oysters ( $\mu \mathrm{g} \mathrm{g}^{-1}$ dry weight) at Riec sur Bélon (station H2) before and after the Erika wreck.
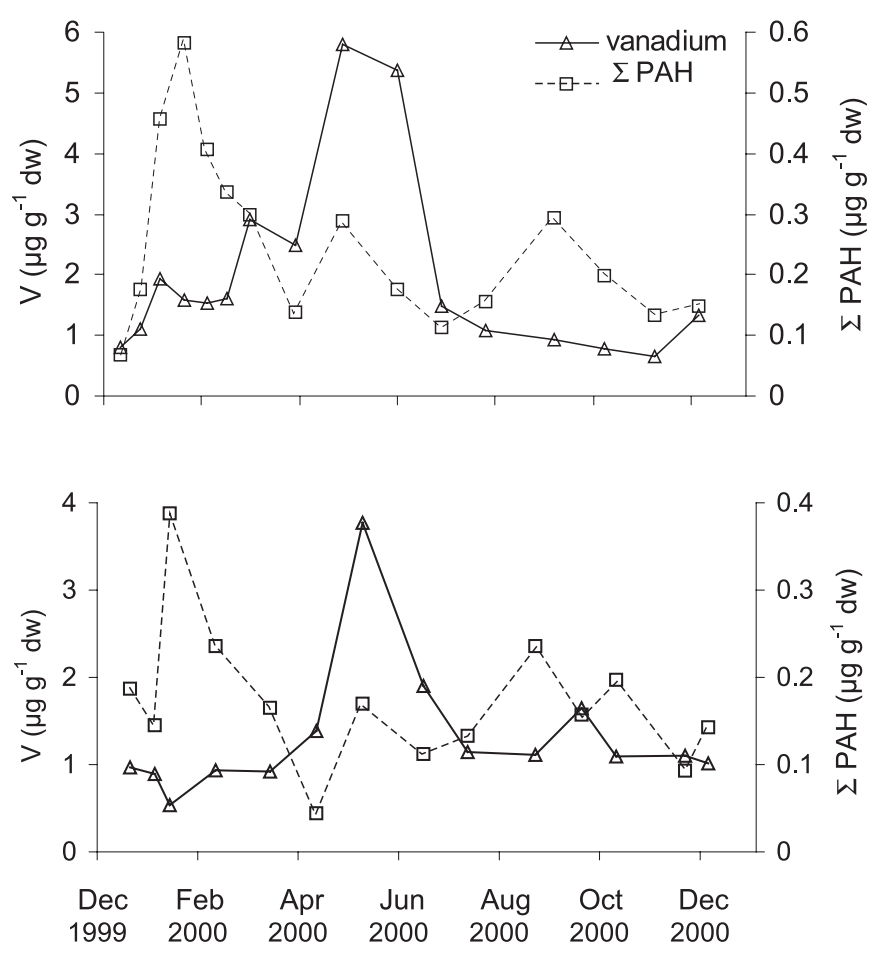

Fig. 6. Comparison of the evolution of vanadium and PAH concentrations in mussels at Poulguin (station M3) and in oysters at Men er Roué (station H4) after the Erika wreck.

attributed with certainty to the oil spill. As opposed to nickel, we observed a very intense peak of vanadium levels in mussels as well as in oysters during the spring of 2000, with maximum concentrations of 4.6 and $3.2 \mu \mathrm{g} \mathrm{g}^{-1} \mathrm{dw}$, respectively, much higher than concentrations observed in this region in the spring of 1999 (Fig. 3), and which can definitely not be assimilated to naturally occurring seasonal variations illustrated by cadmium curves.

When comparing the evolution of vanadium concentrations during the year 2000 and that of PAH - in mussels (Fig. 6 top) from Poulguin (station M3) and oysters (Fig. 6 bottom) from Men er Roué (station H4), for instance - we notice that there is a time difference between the moment at which each maximum occurs. Concentrations in PAH increased as soon as oil slicks reached the shore (end of December 1999) 

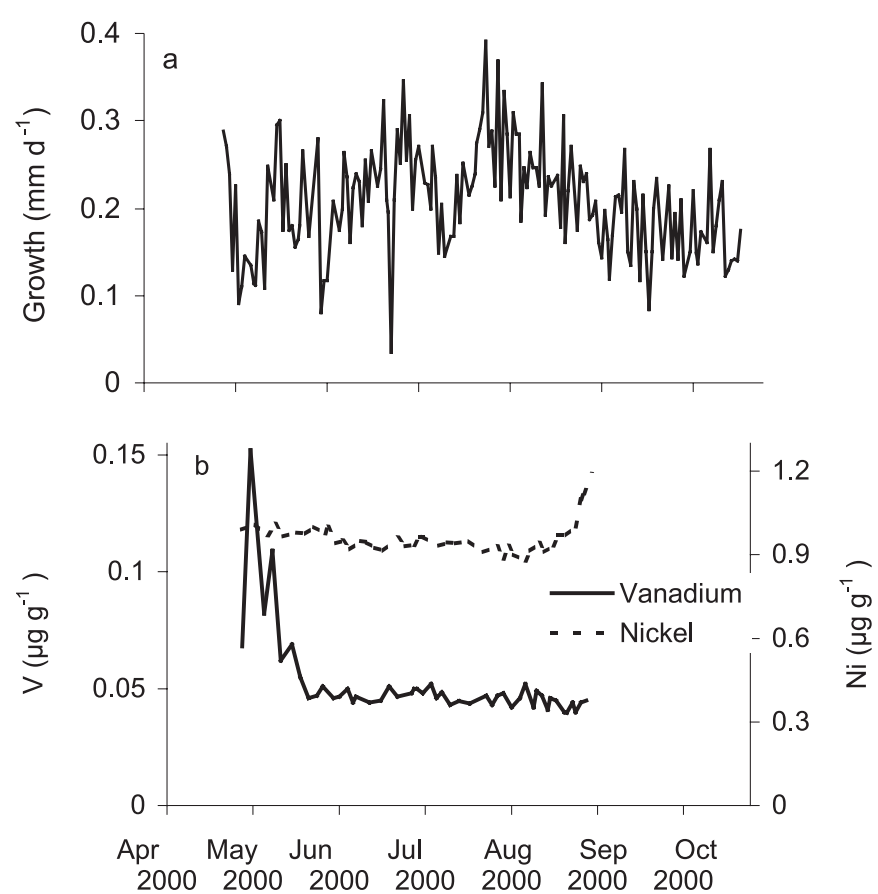

Fig. 7. Scallop shell growth (a) and time evolution of nickel and vanadium concentrations (b) in scallop shells collected off of Belle-Ile (station S8) after the Erika wreck.

and reached maximum values during the month of January, while maximum concentrations of vanadium were reached in May in mussels from Poulguin as well as in oysters from Men er Roué.

Scallops. Growth of scallop shells collected off of BelleIle (station S8), was on the order of 0.1 to $0.3 \mathrm{~mm} \mathrm{~d}^{-1}$ (Fig. 7) from May to October 2000. During that period, the Ni concentration was remarkably stable around $0.9 \mu \mathrm{g} \mathrm{g}^{-1}$ after Ca normalisation. For vanadium, on the other hand, a very intense peak concentration, which reached $0.15 \mu \mathrm{g} \mathrm{g}^{-1}$ and was centred around the beginning of May, was followed by a very rapid return to baseline, where concentrations stabilised around $0.05 \mu \mathrm{g} \mathrm{g}^{-1}$ until the end of the growth period. Further validation must be now achieved on other individuals after this single shell investigation.

\section{Discussion}

In a punctual environmental study, aiming at characterising an accidental event, it is indispensable to reframe the data obtained in this context, based on reference values. Description of the initial conditions must be able to give a clear picture of the general context (chronic contamination of the seashore, reference concentrations) and historical trends, as well as the importance of natural variability. The monitoring program RNO does that perfectly well and notably shows the importance of seasonal variations (Figs. 4 and 5 show contaminant concentration ratios of around 3 between the different seasons), avoiding wrong interpretations. Using the RNO data also make it possible to identify differences in bioaccumulation factors for nickel and vanadium as a function of species.
A mussel-watch-type monitoring program only studies elements that can be bioaccumulated. Such a network however, cannot, due to the costs involved, take into account all the chemicals potentially present in the environment, and in particular, those that are rarely found in hazardous concentrations. In order to remedy the situation, the French strategy, consisting in systematically preserving collected samples in good conditions in an organism bank, perfectly served this purpose. In the case of the Erika wreck, it was thus possible to reconstitute a posteriori historical trends of a contamination with elements that had not previously been monitored. The RNO program however has its limitations, and this study shows that in the event of accidental pollution, the sampling strategy must be adapted to the purpose of the analysis: the number of sampling stations must be increased in order to precisely define the spatial extent, and sampling frequency must be higher than in a routine monitoring program, with time interval between each sample collection in the range 1-2 weeks.

Lastly, a monitoring program based on the measurement of contaminant concentrations in mollusc tissues requires realtime sampling. Indeed the contaminant concentration in the mollusc soft tissues is a function of exposition and time. In particular when exposition ceases, a several weeks depuration time follows (Miramand and Fowler 1998; Punt et al. 1998), during which contaminant concentrations decrease in the mollusc until they reach a new equilibrium - i.e., generally the same concentrations than before the contamination event. This means that animals do not keep a quantitative record of past contaminations in their tissues. So in case of accidental event, the suitable strategy is to collect organisms more frequently than during routine monitoring periods, select and analyse the key samples and store the others until complementary investigations.

The study of the contamination of the marine environment through the analysis of daily growth bands in scallop shells by ICP-MS after laser ablation is remarkably complementary: as opposed to soft tissues, there is no depuration phenomenon in the shell which thus keeps a definitive record, in each growth bands, of metal contamination that occurred in its environment at the time this growth band was elaborated. This means that sampling can be done several months after the event, and as a consequence the sampling strategy can be optimised, upon, of course, availability of resource. In the same way, the frequency of sampling on a shell by laser ablation (interval between the daily bands that are analysed) will also be adapted a posteriori as need be, as the laser ablation technique allows for the analysis of each individual daily growth bands if necessary. Consequently, this type of monitoring, such as that of mussel and oyster tissues, can, although with a much better resolution, provide information on concentrations outside the impact zone (reference concentrations), and concentrations in the impact zone immediately before the accident. This monitoring method is able to determine the exact date of the return to the initial state. As soon as the animal is no longer exposed to the contaminant, contaminant concentration in the new growth band instantly decreases when compared to the previous band (there is no depuration time). The main problem of this method lies in the sophistication of the analysis, although with the development of a rigorous analytical protocol 
we expect a drastic simplification of the procedures involved. The second problem is that it can't be done during winter.

This study aimed at monitoring the evolution of nickel and vanadium contamination in molluscs. It gave however the opportunity of developing innovating techniques and allowed the formulation of hypotheses regarding the phenomena that may be responsible for the observed situation, i.e. a vanadium contamination of the marine environment (Figs. 4 and 5) which was delayed as opposed to the PAH contamination (Fig. 6). This suggests that vanadium was effectively bioavailable for molluscs after the spill, although not immediately after it. Knowing that vanadium is mainly found as porphyrin complexes in crude oil-these are very stable complexes (Guidroz and Sneddon 2002), which causes this element to be found in the heaviest fractions in the refinement processes (Sasaki et al. 1998) - and that these complexes are not very likely to transfer to the aqueous phase (Wang et al. 1999; Cantu et al. 2000), we cannot draw the hypothesis that vanadium was naturally released of from oil slicks that have been washed ashore. Sasaki et al. (1998) have shown that in 45 days, less than $10 \%$ of vanadium is released from crude oil due to oil-degrading micro-organisms. We cannot either hypothesise that vanadium concentration peaks in molluscs were attributable to ingestion of pellets of oil, as this would have translated into concomitant PAH concentration peaks, which was not observed (Fig. 6). Thus vanadium is more likely to have been released from its host by unnatural means. Cantu et al. (2000) report that the use of surfactants promotes transfer of vanadium to the aqueous phase. This hypothesis may be considered, although it does not totally account for the delay in the appearance of the vanadium concentration peak, nor for the brevity of the contamination, notably evidenced by the analysis of scallop shells. In addition, the role of the primary production in the transfer of vanadium to higher trophic levels may be proposed to account for the contamination of mollusc tissues, as proposed by Miramand et al. (1980), as the period at which the peak was detected coincides with a spring bloom, a time-limited phenomenon which usually occurs at that time of the year in the Bay of Biscay (Herbland et al. 1998).

This study was not able to demonstrate the occurrence of a nickel contamination, neither in oyster and mussel tissues nor in scallop shells. The stability of vanadium porphyrin complexes in oil must be considered, and further investigations on the comparative evolution of nickel and vanadium porphyrin complexes in the marine environment may provide useful key information.

\section{Conclusion}

The concomitant use of two types of bioindicators to define the modalities of a marine monitoring program to carry out in the event of an accidental oil spill, was able to show (1) that there has been a relatively important contamination of the water column by vanadium, which is in high concentrations in heavy fuel oil and its derivatives; (2) that nickel, which is also present in high concentrations in heavy fuel oil has not been detected using this monitoring method; (3) that there was a several months delay between the time at which oil slicks washed ashore and the time of apparition of vanadium peaks in soft tissues and shells and (4) that the peak concentration was only observed for a brief period of time. Altogether this means that a "mussel-watch" type of monitoring program, which does not include high frequency sampling, is not very likely to detect traces of such an accident. On the other hand, this monitoring program provides a solid data base from which the initial conditions, before the chronic contamination, can be determined. Conversely, assessment of metal contamination using daily growth bands in scallop shells collected several months after an oil spill may provide precise information on the distribution and transport of released vanadium. In order to improve our understanding of these phenomena, however, and tentatively explain these observations, further studies on the maturation of heavy fuel oil and mobilisation of vanadium contained in the latter within the water column are warranted.

Acknowledgements. The authors are grateful to the staff of the IFREMER coastal laboratories who collected the numerous samples for this study, and to the Rouen Municipal laboratory for the PAH analysis. We are also grateful to Mrs Isabelle Brisson for assistance in English language.

\section{References}

Anderson C.M., Labelle R.P., 2000, Update of comparative occurrence rates for offshore oil spills. Spill Sci. Technol. Bull. 6, 303-321.

Beliaeff B., Smith P.J., 1996, Estimation of coastal water contamination long-term trend using seasonal linear models. J. Am. Water Resour. Assoc. 32, 595-603.

Bu-Olayan A.H., Al-Yakoob S., 1998, Lead, nickel and vanadium in seafood: An exposure assessment for Kuwaiti consumers. Sci. Total Environ. 223, 81-86.

Cantu R., Stencel J.R., Czernuszewicz R.S., Jaffe P.R., Lash T.D., 2000, Surfactant-enhanced partitioning of nickel and vanadyl deoxophylloerythroetioporphyrins from crude oil into water and their analysis using surface-enhanced resonance raman spectroscopy. Environ. Sci. Technol. 34, 192-198.

Chantereau S., Chiffoleau J.-F., Dufour A., Jeanneret H., 2003, Utilisation des données du RNO dans le cadre du naufrage de l'Erika. Surveillance du Milieu marin ; travaux du RNO. Editions IFREMER, Plouzané, France, pp. 25-43.

Chiffoleau J.-F., Bonneau C., 1994, Chromium content in French coastal mussel and oysters. Mar. Pollut. Bull. 28, 458-460.

Chiffoleau J.-F., Auger D., Chartier E., Grouhel A., 2002, Dosage de certains métaux traces $(\mathrm{Ag}, \mathrm{Cd}, \mathrm{Cr}, \mathrm{Cu}, \mathrm{Ni}, \mathrm{Pb}, \mathrm{V}, \mathrm{Zn})$ dans les organismes marins par absorption atomique. Méthodes d'analyse en milieu marin. Editions IFREMER, Plouzané, France.

Claisse D., 1989, Chemical contamination of French coasts. The results of a ten years Mussel-Watch. Mar. Pollut. Bull. 20, 523-528.

Cossa D., 1989, A review of the use of Mytilus edulis sp. as quantitative indicators or cadmium and mercury contamination in coastal waters. Oceanol. Acta 12, 417-432.

Crans D.C., Amin S.S., Keramidas A.D., 1998, Chemistry of relevance to vanadium in the environment. In: Nriagu, J.O. (Ed.), Vanadium in the Environment. Part I: Chemistry and Biochemistry. John Wiley and sons, pp. 73-96.

Dyrynda E.A., Law R.J., Dyrynda P.E.J., Kelly C.A., Pipe R.K., Ratcliffe N.A., 2000, Changes in immune parameters of natural mussel Mytilus edulis populations following a major oil spill ("Sea Empress", Wales, UK). Mar. Ecol. Prog. Ser. 206, 155-170. 
Guidroz J.M., Sneddon J., 2002, Fate of vanadium determined by nitrous oxide - acetylene flame atomic absorption spectrometry in unburned and burned Venezuelian crude oil. Microchem. J. 73, 363-366.

Herbland A., Delmas D., Sautour B., Artigas F., 1998, Phytoplankton spring bloom of the Gironde plume waters in the Bay of Biscay: early phosphorus limitation and food-web consequences. Oceanol. Acta 21, 279-291.

Highsmith R.C., Rucker T.L., Stekoll M.S., Saupe S.M., Lindeberg M.R., Jenne R.N., Erickson W.P., 1996, Impact of the Exxon Valdez oil spill on intertidal biota. In :Rice, S.D., Spies, R.B., Wolfe, D.A., Wright, B.A. (Eds.). Proceedings of the Exxon Valdez symposium. Bethesda, MD (USA). 18, 212-237.

Jones D.A., Plaza J., Watt I., Sanei M.A., 1998, Long-term (19911995) monitoring of the intertidal biota of Saudi Arabia after the 1991 Gulf War oil spill. Mar. Pollut. Bull. 36, 472-489.

Larvor H., 1996, Biomineralization of Pecten maximus L.: anomalies connected with the environmental disturbances. Thesis. Université de Bretagne Occidentale, Brest.

Law R.J., Kelly C.A., Nicholson M.D., 1999, Polycyclic aromatic hydrocarbons (PAH) in shellfish affected by the Sea Empress oil spill in Wales in 1996. Polycycl. Aromatic. Comp. 17, 229-239.

Lee R.F., Page D.S., 1997, Petroleum hydrocarbons and their effects in subtidal regions after major oil spills. Mar. Pollut. Bull. 34, 928-940.

Le Hir M., Hily C., 2002, First observations in a high rocky-shore community after the Erika oil spill (December 1999, Brittany, France). Mar. Pollut. Bull. 44, 1243-1252.

Márquez N., Ysambert F., De La Cruz C., 1999, Three analytical methods to isolate and characterize vanadium and nickel porphyrins from heavy crude oil. Anal. Chim. Acta 395, 343-349.
Metwalli M.E.S., Al-Muzaini S., Jacob P.G., Bahloul M., Urushigawa Y., Sato S., Matsmura A., 1997, Petroleum hydrocarbons and related heavy metals in the near-shore marine sediments of Kuwait. Environ. Internat. 23, 115-121.

Miramand P., Guary J.-C., Fowler S.W., 1980, Vanadium transfer in the mussel Mytilus galloprovincialis. Mar. Biol. 56, 281-293.

Miramand P., Fowler S.W., 1998, Bioaccumulation and transfert of vanadium in marine organisms. In: Nriagu, J.O. (Ed.), Vanadium in the Environment. Part I: Chemistry and Biochemistry. John Wiley and sons, pp. 167-197.

Punt A.G., Milward G.E., Jones M.B., 1998, Uptake and depuration of ${ }^{63} \mathrm{Ni}$ by Mytilus edulis. Sci. Total Environ. 214, 71-78.

Richardson C.A., Chenery S.R.N., Cook J.M., 2001, Assessing the history of trace metal $(\mathrm{Cu}, \mathrm{Zn}, \mathrm{Pb})$ contamination in the North Sea through laser ablation - ICP-MS of horse mussel Modiolus modiolus shells. Mar. Ecol. Prog. Ser. 211, 157-167.

Sasaki T., Maki H., Ishihara M., Harayama S., 1998, Vanadium as an internal marker to evaluate microbial degradation of crude oil. Environ. Sci. Technol. 32, 3618-3621.

Seip K.L., 1984, The Amoco Cadiz oil spill - at a glance. Mar. Pollut. Bull. 15, 218-220.

Sturesson U., 1976, Lead enrichment in shells of Mytilus edulis. Ambio 5, 253-256.

Sturesson U., 1978, Cadmium enrichment in shells of Mytilus edulis. Ambio 7, 122-125.

Vale M.G.R., Damin I.C.F., Klassen A., Silva M.M., Welz B., Silva A.F., Lepri F.G., Borges D.L.G., Heitmann U., 2004, Method development for the determination of nickel in petroleum using line-source and high-resolution continuum-source graphite furnace atomic absorption spectrometry. Microchem. J. in press.

Wang Z., Fingas M., Page D.S., 1999, Oil spill identification. J. Chromatogr. A. 843, 369-411. 